\title{
The Relationship among Indonesian Women Self-Esteem with Breast Cancer Beliefs Screening: Attitude, Knowledge, and Barriers to Mammographic
}

\author{
Achmad Sholeh $^{1 *}$, Nurul Hidayah ${ }^{2}$ and Winda Sri Harianti ${ }^{3}$ \\ ${ }^{1,3}$ Department of Psychology, Faculty of Psychology and Socio-Cultural Sciences, Universitas \\ Islam Indonesia, Indonesia \\ ${ }^{2}$ Department of Medical Education, Faculty of Medicine, Universitas Islam Indonesia, \\ Indonesia
}

\begin{tabular}{|c|c|}
\hline ARTICLE INFO & ABSTRACT \\
\hline $\begin{array}{l}\text { Keywords: } \\
\text { Breast Cancer Beliefs } \\
\quad \text { Screening } \\
\text { Self-Esteem } \\
\text { Attitude } \\
\text { Knowledge } \\
\text { Barriers }\end{array}$ & $\begin{array}{l}\text { Breast cancer is one of the prevalent non-communicable diseases in } \\
\text { developed and under-developed countries, especially Indonesia. It's } \\
\text { necessary to promote and aware breast cancer screening practices for } \\
\text { early detection of breast cancer. This study aims to analyze } \\
\text { relationship between self-esteem and breast cancer beliefs screening } \\
\text { among Indonesian women. This study was conducted with a } \\
\text { quantitative approach and performed in Indonesia. Participants of this } \\
\text { study were } 209 \text { women. Measurement of self-esteem was done by } \\
\text { using Rosenberg's Self-Esteem Scale by Rosenberg, and breast } \\
\text { cancer beliefs screening was measured using adaptation of Breast } \\
\text { Cancer Screening Beliefs Questionnaire by Kwok, et al. The Results } \\
\text { of data analysis showed that self-esteem has positive correlation with } \\
\text { knowledge ( } \mathrm{r}=.131, \mathrm{p}=.029) \text { and negative correlation with barriers } \\
\text { to mammographic screening }(\mathrm{r}=-.128, \mathrm{p}=.039) \text { but, there is no } \\
\text { correlation with attitude }(\mathrm{r}=.091, \mathrm{p}=.096) \text {. From the results, it can } \\
\text { be concluded that Indonesian women with high self-esteem has more } \\
\text { knowledge and has little barriers to mammographic screening. }\end{array}$ \\
\hline
\end{tabular}

1. Introduction

Breast cancer is a high cause of women's death in worldwide (Broeders et al., 2016; Jemal et al., 2009). The mortality rate is about 1.4 deaths per 100 inhabitants and increases every year depends on the risk of each country (Ghoncheh et al., 2016). The incident rate of breast cancer is 100> higher in women than men (Jemal et al., 2009) and the percentage of breast cancer is $11,6 \%$ from the total of new cancer cases and 6,6\% of the total cancer deaths in 2018 (Globocan, 2019). According to data, Asia has the largest percentage of breast cancer incidence $(43,6 \%)$, mortality $(49,6)$, and 5-year prevalence $(38,2 \%)$ from the total in global (Globocan, 2019). Moreover, it is known as the second leading of non-communicable disease among women across the world(KEMENKES RI, 2016). The prevalence is much higher in low and middle-income countries i.e. Indonesia as part of south eastern Asian countries, compared to Western countries (Solikhah et al., 2018). Based on the Health Ministry Indonesia (2016), the incidence of breast cancer reported as a second rank in the Asian country, moreover it has 23.140 new cases in a year (Suyatno \& Emir, 2014). The high rates of mortality and morbidity in Indonesia reflected by the fact of poor detection, screening, and awareness of the disease (Oeffinger et al., 2015). Most of the diagnosed known at end-stage of the disease which advanced treatments were not adequate to inhibits the cell growth of the cancer (Solikhah et al., 2018).

\footnotetext{
* Corresponding author E-mail address: zholeh.wei@gmail.com 
Breast cancer screening has a principal goal to lessen mortality from breast cancer disease (Galdon et al., 2011; IARC, 2002) and to detect cancers before they clinically proven as the immediate goals and also to detect cancers before they clinical appearance increases a risk of diagnosis and treatment(IARC, 2002). Mammography is the preferential test of breast cancer disease for early detection and has been studied over the past 50 years in more than 600,000 (Galdon et al., 2011). Early detection is highly convinced to reduce breast cancer mortality. It seems on clinical data that women who diagnosed with early-stage of breast cancers are less likely to die than those diagnosed with more progressive stages of breast cancer. As the results in the United State, screening mammography procedures has obtained a place as part of routine health procedures for women (Institute of Medicine \& National Research Council, 2001).

Hanson et al. (2017) have founded that the respondent is not able to do self-screening as much as $228(66.1 \%)$ women, in otherwise 117 (33.9\%) women are able to do self-screening of breast cancer (Hanson et al., 2017). Furthermore, Solikhah Sangruangake, and Promthet (2018) reported that the urban Indonesian women with highly educated like bachelor degree had poor breast cancer screening. Whereas the urban women have significance than rural woman of knowledge related to breast cancer (AOR: 1.44, 95\% Cl: 1.07, 1.96, p<0.05), while the highly educated women who's completed the level education had 2.95 times the odds of higher knowledge of risk factors of breast cancer (AOR: 2.95, 95\% Cl: 1.16, 7.49, p<0.05) (Solikhah et al., 2018).

However, from the recent studies known that women still lack of understanding the benefit of breast cancer beliefs screening. If there is problem with the breast, it results in psychological problems such as the chance of breast cancer spreading to the other parts of the body, uncertainty about the future, anxiety, depression, anger, despair, pain, alteration in body image, diminished self-esteem and the fear of losing femininity(Avci et al., 2014). Based on previous research, it can be seen that low self-esteem can be factors that influence breast cancer screening. Self-esteem as a predisposing factor for preventive health behaviour, people who low self-esteem has more health problem than people who has high self-esteem(Brewer \& Baldwin, 2000; Glaser, 1993; Schare, 1993).

Avci, Kumcagiz, Altinel, and Caloglu (2014) reported that self-esteem correlated with perceived seriousness of breast cancer and perceived barriers to breast cancer screening. Self-esteem contribute to a woman decision to perform breast self-examination (Champion \& Miller, 1992). Other studies also found that woman who practice breast self-examination routinely has level of self-esteem highly (Brewer \& Baldwin, 2000; Cope et al., 1992).

The purpose of this study is to establish the relationship between self-esteem and breast cancer screening beliefs among Indonesian women. Therefore, it is necessary to promote and aware breast cancer screening practices for early detection of breast cancer. In this case, there is a relationship between self-esteem and breast cancer screening beliefs among Indonesian women?

\section{Method}

\subsection{Participant and Procedure}

The convenience sampling technique was used for sample selection. A total 209 Indonesian women for the final sample, ranging from 17 to 28 years who were resident of Indonesia were included in this study. The majority origin from Kalimantan, Sulawesi, Riau, and Java Province- Indonesia.

\subsection{Data collection}

This study was done by quantitative research to test empirically correlation between selfesteem and breast cancer beliefs screening. Data was collected using self-report scale for two variables. 


\subsection{Measurement}

Breast cancer screening in this study was adapted from Breast Cancer Screening Beliefs Questionnaire (BCBSQ). This scale was developed by Kwok et al. Instrument composed of three subscales with 13 items: 1) attitudes towards general health check-ups with a subscale of four items designed to ascertain whether a women had general health check-ups in the absence of signs and symptoms (e.g., "If I feel well, it is not necessary to have a health check-up"; 2) knowledge and perceptions about breast cancer (four items) which explored cultural beliefs relating to breast cancer (e.g., Breast cancer is like a death sentence; if you get it, you will surely die from it); and 3) barriers to mammographic screening practices (five items) which covered personal and practical issues perceived by women to hinder their participation in breast cancer screening (e.g., I'm worried that having a mammogram will hurt my breasts") (Kwok et al., 2016). Confirmatory factor analyses (CFAs) with the Indonesia form indicated that scale has a good fit (root mean square residuals (RMSEA) $=0.05$, bollen's incremental fit index (IFI) $=0.96$, comparative fit index $(\mathrm{CFI})=0.96$, tucker-lewis index $(\mathrm{TLI})=0.95$, bentler-bonett norm fit index $(\mathrm{NFI})=0.90$, bentler-bonett non-standard fit index $(\mathrm{NNFI})=0.95$, relative noncentrality index $(\mathrm{RNI})=0.96$, goodness of fit index $(\mathrm{GFI})=0.93$, mcdonald fit index $(\mathrm{MFI})$ $=0.91$ ). Reliability coefficient (Cronbach Alpha Coefficient) of this scale was 0.87 (attitude), 0.83 (knowledge), and 0.69 (barriers to mammographic screening).

Self-esteem scale in this study was adapted from Rosenberg Self-Esteem Scale (RSES). This scale was developed by Rosenberg. The scale comprises 10 items on a 4-point Likert scale from "strongly disagree" to "strongly agree." This scale used to assess global self-esteem or explicit self-esteem such as "on the whole, I am satisfied with myself," "I feel I do not have much to be proud of," and "I take a positive attitude toward myself" (Rosenberg, 1965). Confirmatory factor analyses (CFAs) with the Indonesia form indicated that scale has a good fit $($ root mean square residuals $($ RMSEA $)=0.07$, bollen's incremental fit index $($ IFI $)=0.91$, comparative fit index $(\mathrm{CFI})=0.91$, relative noncentrality index $(\mathrm{RNI})=0.91$, goodness of fit index $(\mathrm{GFI})=0.94$, mcdonald fit index $(\mathrm{MFI})=0.92$, residual covariances model between item 3 with item 4, estimate $=-0.074 ; \mathrm{p}<0.01$ ) and item 7 and item 8 , estimate $=0.083 ; \mathrm{p}<0.01$ ). Reliability coefficient (Cronbach Alpha Coefficient) of this scale was 0.70 .

\subsection{Data Analysis}

This study used correlation analysis to analyse relationship between self-esteem and breast cancer screening (Attitude, Knowledge, and Barriers to Mammographic). This analysis method used to correlate each scale.

\section{Results and Discussion}

This study is intended to test empirically relation of self-esteem and breast cancer screening among Indonesian women. The demographic characteristics of the women who participated in the research are shown in Table 1.

Table 1.

Demographic Characteristics

\begin{tabular}{lcc}
\multicolumn{1}{c}{ Characteristic } & N $(\boldsymbol{\%})$ & $(\%)$ \\
\hline Age (year) (Mean: 19.47, SD: 1.93) & & \\
$\quad>20$ & 162 & 77,5 \\
$20-28$ & 47 & 22,5 \\
Origin (Provinces of Indonesia) & 76 & 36 \\
$\quad$ Sulawesi & 45 & 22 \\
Java & 19 & 9 \\
Kalimantan & 16 & 7,7 \\
Riau & 9 & 4 \\
Sumatra & & \\
\hline
\end{tabular}




\begin{tabular}{lcc}
\hline \multicolumn{1}{c}{ Characteristic } & $\mathbf{N ~ ( \% )}$ & $\mathbf{( \% )}$ \\
\hline Yogyakarta & 8 & 3,8 \\
Gorontalo & 8 & 3,8 \\
Banten & 6 & 2,9 \\
Nusa Tenggara Barat & 4 & 1,9 \\
Bangka Belitung & 5 & 2,4 \\
Lampung & 3 & 1,4 \\
Papua & 2 & 1 \\
Jakarta & 2 & 1 \\
Maluku & 2 & 1 \\
Bengkulu & 1 & 0,5 \\
Aceh & 1 & 0,5 \\
Bali & 1 & 0,5 \\
Others & 1 & 0,5 \\
Works & & \\
University Students & 200 & 95,5 \\
Workers & 7 & 3,3 \\
Others & 2 & 1 \\
\hline
\end{tabular}

*Only most important listed

Data showed that mean of age Indonesian women was calculated (Mean: 19.47, SD: 1.93). The majority origin from Sulawesi (36\%), Java (22\%), Kalimantan (19\%), and Riau (16\%). 95,5\% of participants were university students, 3,3\% workers, and $1 \%$ others. Furthermore, to test hypothesis of this study, we used correlation analysis. Correlation analysis result can be seen in Table 2 below

Table 2.

Correlation Self-Esteem and Breast Cancer Screening

\begin{tabular}{|c|c|c|c|c|c|c|}
\hline Variables & $\mathbf{M}$ & Std. Deviation & 1 & 2 & 3 & 4 \\
\hline 1. Self-Esteem & 27.55 & 3.198 & 1 & & & \\
\hline 2. Attitudes & 11.4067 & 3.43933 & .091 & 1 & & \\
\hline 3. Knowledge & 14.1962 & 3.11861 & $.131^{*}$ & $.170^{* *}$ & 1 & \\
\hline 4. Barriers to Mammographic Screening & 13.0574 & 2.74677 & $-.128^{*}$ & $-.308^{* *}$ & $-.430^{* *}$ & 1 \\
\hline
\end{tabular}

$* \mathrm{P}>0.05 ; * * \mathrm{P}>0.01$

Based on data analysis, results showed that self-esteem has the value of $\mathrm{M}=27.55 ; \mathrm{SD}=3.198$, attitudes $\mathrm{M}=11.4067 ; \mathrm{SD}=3.43933$, knowledge $\mathrm{M}=14.1962 ; \mathrm{SD}=3.11861$, and barriers to Mammographic Screening $M=13.0574 ; S D=2.74677$. Self-esteem has no correlation with subscale attitude $(\mathrm{p}=0.96, \mathrm{p}>0.05 ; \mathrm{r}=0.09$. Meanwhile, self-esteem has positive correlation with subscale knowledge $(\mathrm{p}=0.02, \mathrm{p}>0.05 ; \mathrm{r}=0.13)$ and has negative correlation with Barriers to Mammographic Screening ( $\mathrm{p}=0.03 \mathrm{p}<0.05 ; \mathrm{r}=-0.12)$.

The finding of this study show that self-esteem has association with breast cancer beliefs screening, particularly self-esteem towards knowledge and barriers to mammographic screening, which the result portrays that the higher self-esteem, the higher knowledge and lower barriers to mammographic screening. It can be seen as noteworthy finding because to see the success of any early detection program, it does not solely about the effectively of the clinical technique used, which is the screening technique with mammogram, but also on the participation (Galdon et al., 2011).

The data showed that self-esteem has no correlation with subscale attitude in Indonesian women, particularly attitude towards general health check-up. Attitude describe as general evaluations towards objects, people or issues. Study in Indonesia portray that negative attitude evidently as one of factors that influence patients of cancer behavior towards medical health check-up (Susanti et al., 2003). According to Rath and Deb (2017) that increasing awareness on people in rural area will help them to build positive behavior towards regular health check-up. Moreover, 
level of people awareness toward general health check-up in Indonesia is still low, approximately only reach 20\% (RISKESDAS, 2018). The majority of Indonesian people are still lack of selfawareness level and this still become predicament stage to further examine about attitude toward general health check-up. Self-esteem seen as attitude towards self and self-beliefs as constituent of self-esteem that associate or dissociate self by different attributes. The type of beliefs as best constituent that can predict self-esteem is predisposed by gender groups in ethnicity. It can be seen that the correlation between self-esteem and attitude can be found with different results based on society cultural beliefs (Tashakkori, 1993) and this finding is parallel with another study that the development of self-esteem is determined by multiple macro psychological mechanism factors in cultural cross the world (Bleidorn et al., 2016).

Furthermore, this study found that self-esteem has positive correlation with subscale knowledge. Our study showed consistent results with previous studies, where this study can prove that self-esteem is closely correlated with knowledge level. Lack knowledge of benefit to screening services have been identified as one of a number of factors that influence a participation in cancer screening programs (Kwok et al., 2010). Women's decision to implement breast self-examination is influenced by self-esteem and capabilities of knowledge towards cancer screening and practices that women have (Champion \& Miller, 1992). The similar finding is further illustrated from another study that higher self-esteem have found in women who perform breast self-examination routinely (Schare, 1993). It can be seen that women who higher in self-esteem and having high level of knowledge about breast cancer screening can support and contribute to increase the effectively of breast cancer screening participation. This is notable finding to mitigate the primary impediments of breast cancer screening effectively, which are the large gaps in people knowledge about the disease (Tandon \& Fentiman, 2011).

Self-esteem also has negative correlation to barriers of mammographic screening significantly. This study also consistent with previous studies. Avci, Kumcagiz, Altinel, and Caloglu (2014) suggested that self-esteem correlated with perceived barriers to breast cancer screening. The women with high self-esteem were more hopeful about the future, had positive body images, and paid more attention to their own health and breast cancer screening (Avci et al., 2014; Cevik et al., 2005). Women who are more likely to take part on mammogram procedure demonstrate lower barriers to screening and higher level of confidence (Lee et al., 2014). The barriers of mammography screening practices is proved of women who are noncompliers in mammography screening with significantly higher total barriers scores than compliers (Rimer et al., 1989). Moreover, emotional, knowledge, structural, and financial are deduced as varieties of barriers towards breast cancer screening (Kwok et al., 2010; O'Hara et al., 2018). Kwok et al. (2017) examined that enhancing knowledge about breast cancer will diminish barriers of mammographic screening and contribute to women's decision making to screen (Beauchamp et al., 2015).

A cross-cultural study perspective, Bleidorn et al. (2016) depict that male tend to have higher self-esteem than female in cultures across the world. A similarity pattern on this cross-cultural study conclude that cultural differences contribute to shape age and gender differences in selfesteem, and evidently prove that there are contextual influences on self-esteem development in male and female. Another finding reveals that throughout early and middle adult-hood, selfesteem tend to increase, specifically in collectivistic and developing nations with greater gender inequality and small gender gap compared to individualistic, developed nations with higher gender equality and larger gender gaps in self-esteem. According to the report, Asian countries, such as Thailand, Indonesia, China and India were small in gender gap. It can be said that selfesteem in Indonesian people indicate to increase during the early and adulthood stage. In consequence, the increasing of self-esteem, particularly in Indonesian people can be noteworthy finding of study towards breast cancer belief screening participant, which exhibit 
the significant role as early detection and preventive way of breast cancer cases in Indonesia and will complement to examine the further study of this research.

Some limitations possibility made this research not proven. The sample population of this study is Indonesian women, which is native from variety of provinces in Indonesia. However, to consider the external validity from the result of this study, the further research should obtain more sample that can represent the general characteristic of Indonesian women from every province in Indonesia. Furthermore, this study examines the personal aspects of women that affected by cultural beliefs of particular society, which are self-esteem towards attitude, knowledge and barriers to mammography. Therefore, the specific characteristic of women and society where they live, such as cultural value is notable to complement the examination of further study. Particularly on self-esteem, it is prominent to examine more about the development of self-esteem based on gender differences, age and more biological and sociocultural influences to complement the future research, especially to predict breast cancer beliefs screening participation among women in Indonesia.

\section{Conclusion}

Based on the results of this study, self-esteem has positive correlation with knowledge and negative correlation with barriers to mammographic screening. It can be concluded that Indonesian women with high self-esteem has more knowledge and has little barriers to mammographic screening.

Informed Consent: Written informed consent was obtained from participants who participated in this study.

Acknowledgements: We thanks to Department of Psychology and Department of Medical Education, Universitas Islam Indonesia for the collaboration on this project.

\section{References}

Avci, I. A., Kumcagiz, H., Altinel, B., \& Caloglu, A. (2014). Turkish female academician selfesteem and health beliefs for breast cancer screening. Asian Pacific Journal of Cancer Prevention, 15(1), 155-160. https://doi.org/10.7314/APJCP.2014.15.1.155

Beauchamp, A., Buchbinder, R., Dodson, S., Batterham, R. W., Elsworth, G. R., McPhee, C., Sparkes, L., Hawkins, M., \& Osborne, R. H. (2015). Distribution of health literacy strengths and weakness across socio-demographic groups: A cross-sectional survey using the Health Literacy Questionnaire (HLQ). BMC Public Health, 15(678), 1-13. https://doi.org/10.1186/s12889-015-2056-Z

Bleidorn, W., Arslan, R. C., Denissen, J. J. A., Rentfrow, P. J., Gebauer, J. E., Potter, J., \& Gosling, S. D. (2016). Age and gender differences in self-esteem-A cross-cultural window. Journal of Personality and Social Psychology, 111(3), 369-410. https://doi.org/http://dx.doi.org/10.1037/pspp0000078

Brewer, M. K., \& Baldwin, D. (2000). The relationship between self-esteem, health habits, and knowledge of BSE practice in female inmates. Public Health Nursing. https://doi.org/ 10.1046 j.1525-1446.2000.00016.x

Broeders, M. J. M., Ripping, T. M., \& Hubbard, R. A. (2016). Weighing the benefits and harms: Screening mammography in the balance. In N. Houssami \& D. Miglioretti (Eds.), Breast cancer screening: An examination of scientific evidence (pp. 51-85). Elsevier.

Cevik, C., Akbulut, G., \& Erkal, S. (2005). Effect of women's knowledge level about breast self examination on their detecting a mass. Nurs Forum, 6, 44-49. 
Champion, V. L., \& Miller, T. K. (1992). Variables related to breast self-examination: Model generation. Psychology of Women Quarterly, 16(1), 81-96. https://doi.org/https://doi.org/ 10.1111/j.1417-6402.1992.tb00241x

Cope, D. G., Olson, K., \& Humenick, S. S. (1992). Self-Esteem and the Practice of Breast SelfExamination. Western Journal of Nursing Research, 14(5), 618-631. https://doi.org/ 10.1177/019394599201400505

Galdon, M. J., Dura, E., Andreu, Y., Queipo, S., \& Ibanez, E. (2011). Health beliefs and breast cancer screening: Applying the stage-of-change models. In J. D. Pegg (Ed.), Breast cancer screening and prevention (pp. 21-56). Nova Science Publishers.

Ghoncheh, M., Pournamdar, Z., \& Salehiniya, H. (2016). Incidence and mortality and epidemiology of breast cancer in the world. Asian Pacific Journal of Cancer Prevention. https://doi.org/10.7314/APJCP.2016.17.S3.43

Glaser, J. B. (1993). Correctional Health Care: A Public Health Opportunity. Annals of Internal Medicine, 118(2), 139. https://doi.org/10.7326/0003-4819-118-2-199301150-00010

Globocan. (2019). Cancer fact sheet.

Hanson, V., Adejumo, O., \& Van Wyk, B. (2017). Knowledge and practice of breast selfexamination among rural women in South-West Nigeria: Implications for development of women empowerment programme. Africa Journal of Nursing and Midwifery, 19(1), 144156. https://doi.org/10.25159/2520-5293/950

IARC. (2002). IARC handbooks of cancer prevention: Breast cancer screening (F. Bianchini $\&$ H. Vainio (eds.)). IARCPress.

Institute of Medicine \& National Research Council. (2001). Mammography and beyond: Developing technologies for the early detection of breast cancer (S. J. Nass, I. C. Henderson, $\&$ J. C. Lashof (eds.)). National Academy Press.

Jemal, A., Center, M. M., Ward, E., \& Thun, M. J. (2009). Cancer occurrence. In M. Verma (Ed.), Cancer Epidemiology (pp. 3-29). Humana Press.

KEMENKES RI. (2016, October). Infodatin: Bulan Peduli Kanker Payudara. KEMENKES RI, 19. https://pusdatin.kemkes.go.id/article/view/17013100001/bulan-peduli-kanker-payudara.html

Kwok, C., Fethney, J., \& White, K. (2010). Chinese Breast Cancer Screening Beliefs Questionnaire: development and psychometric testing with Chinese-Australian women. Journal of Advanced Nursing, 66(1), 191-200. https://doi.org/10.1111/j.13652648.2009.05177.x

Kwok, C., Lee, M. J., \& Lee, C. F. (2017). Validation of korean version of Breast Cancer Screening Beliefs Questionnaire (BCSBQ). Cancer Nursing, 40(4), 1-8. https://doi.org/ 10.1097/NCC.0000000000000389

Kwok, C., Pillay, R., \& Lee, C. F. (2016). Psychometric Properties of the Breast Cancer Screening Beliefs Questionnaire Among Women of Indian Ethnicity Living in Australia. Cancer Nursing, 39(4). https://doi.org/10.1097/NCC.0000000000000294

Lee, H. Y., Stange, M. J., \& Ahluwalia, J. S. (2014). Breast cancer screening behaviors among Korean American Immigrant Women: Finding from the health belief model. Journal of Transcultural Nursing, 26(5), 1-8. https://doi.org/10.1177/1043659614526457

O'Hara, J., McPhee, C., Dodson, S., Cooper, A., Wildey, C., Hawkins, M., Fulton, A., Pridmore, V., Cuevas, V., Scanlon, M., Livingston, P. M., Osborne, R. H., \& Beauchamp, A. (2018). Barriers to breast cancer screening among diverse cultural groups in Melbourne, 
Australia. International Journal of Environmental and Public Health, 15(8), 1-13. https://doi.org/10.3390/ijerph15081677

Oeffinger, K. C., Fontham, E. T., Etzioni, R., Herzig, A., Michaelson, J. S., Shih, Y. C. T., ... $\&$ Wender, R. (2015). Breast cancer screening for women at average risk: 2015 guideline update from the American Cancer Society. Jama, 314(15), 1599-1614. https://doi.org/ 10.1001/jama.2015.12783

Rath, N. B., \& Deb, A. (2017). Perception towards regular health check-ups: A case study from a selected village in Telengana State in India. Journal of Health Management, 19(1), 180191. https://doi.org/https://doi.org/10.1177/0972063416682646

Rimer, B. K., Keintz, M. K., Kessler, H. B., Engstrom, P. F., \& Rosan, J. R. (1989). Why women resist in screening mammography: Patient related barriers. Radiology, 172(1), 243246. https://doi.org/10.1148/radiology.172.1.2740510

RISKESDAS. (2018, May). Hasil Utama Riskesdas 2018. KEMENKES RI, 1-220.

Rosenberg, M. (1965). Rosenberg Self-Esteem Scale. New York, ? https://doi.org//S003498872009000600009

Schare, B. (1993). Commentary on self-esteem and the practice of breast self-examination. Nurshing Scan in Research, 6(2), 5-6.

Solikhah, S., Sangruangake, M., \& Promthet, S. (2018). Awareness of breast cancer and its screening among Indonesian women. Journal of Clinical and Diagnostic Research, 12(11), LC36-LC41. https://doi.org/10.7860/JCDR/2018/36943.12297

Susanti, N. N., Aziz, M. F., \& Bachtiar, A. (2003). An analysis on the delay of cervical cancer patients in seeking medical check up in Dr. Cipto Mangunkusumo National Central General Hospital Jakarta. Medical JOURNAL of Indonesia, 12(3), 162-165. https://doi.org/https://doi.org/10.13181/mji.v12i3.105

Suyatno, \& Emir, T. P. (2014). Bedah Onkologi Diagnostik dan Terapi. Sagung Seto.

Tandon, R., \& Fentiman, I. S. (2011). Strategies for prevention of breast cancer. In J. D. Pegg (Ed.), Breast cancer screening and prevention (pp. 1-19). Nova Science Publishers.

Tashakkori, A. (1993). Gender, ethnicity, and the structure of self-esteem: An attitude theory approach. The Journal of Social Psychology, 133(4), 479-488. https://doi.org/https://doi.org/10.1080/00224545.1993.9712172 